\title{
Acute Toxicity of Fresh and Aged Residues of Pesticides to the Parasitoid Tamarixia radiata and to the HLB-Bacteria Vector Diaphorina citri
}

\author{
VH Beloti ${ }^{1}$, GR Alves ${ }^{1}$, RA Moral ${ }^{2}$, CGB Demétrio ${ }^{2}$, PT Yamamoto ${ }^{1}$ \\ ${ }^{1}$ Dept of Entomology and Acarology, "Luiz de Queiroz" College of Agriculture/Univ of São Paulo (ESALQ/USP), Piracicaba, São Paulo, Brasil \\ ${ }^{2}$ Dept of Agricultural Statistics and Experimentation, "Luiz de Queiroz" College of Agriculture/Univ of São Paulo (ESALQ/USP), Piracicaba, São \\ Paulo, Brasil
}

\section{Keywords}

Selectivity, IPM, ecotoxicology, sublethal concentration, differential toxicity

\section{Correspondence \\ VH Beloti, Dept of Entomology and Acarology, ESALQ/USP, 13418-900 Piracicaba, SP, Brasil;} vitorbeloti@usp.br

Edited by Eugenio E de Oliveira - UFV

Received 25 May 2017 and accepted 29 November 2017

Published online: 8 December 2017

(C) Sociedade Entomológica do Brasil 2017

\begin{abstract}
One method for controlling the Asian citrus psyllid (ACP) Diaphorina citri Kuwayama, the vector of the putative causal agent of Huanglongbing, uses the parasitoid Tamarixia radiata (Waterston). However, the general intensive use of insecticides has reduced the numbers of this parasitoid. This study evaluated the effect of the residual action of 24 insecticides on $T$. radiata and also determined the differential toxicity of insecticides to $D$. citri and $T$. radiata, using three bioassays. In the first, when adults of the parasitoid were exposed to residues of the 24 insecticides, ten were considered shortlife (class 1 ), six slightly persistent (class 2 ), five moderately persistent (class 3 ), and three insecticides were considered persistent (class 4), under the IOBC/WPRS classification system. The second bioassay evaluated the sublethal concentrations of the persistent insecticides (formetanate, dimethoate, spinosad). Increasing the concentrations of the insecticides increased the number that were classified as persistent. In the third bioassay, evaluation of the differential toxicity of eight insecticides to the ACP and the parasitoid showed that chlorpyrifos and bifenthrin were more harmful to $T$. radiata. Therefore, these two insecticides are not recommended for application at the time of parasitoid release. Cypermethrin, imidacloprid, and dimethoate caused higher mortality of $D$. citri and are most often recommended in IPM programs. The choice of an insecticide for the control of citrus pests must be made with care, aiming to preserve the natural enemies in the ecosystem, and thereby contribute to the success of biological control.
\end{abstract}

\section{Introduction}

Huanglongbing (HLB) or greening disease is currently the main phytosanitation problem affecting citrus production worldwide (Alemán et al 2007, Grafton-Cardwell et al 2013). HLB is associated with "Candidatus Liberibacter asiaticus" and "Candidatus Liberibacter americanus" (ColettaFilho et al 2004, Teixeira et al 2005). These phloem-limited bacteria are transmitted by the Asian citrus psyllid Diaphorina citri Kuwayama (Hemiptera: Liviidae) (Hall et al 2013, Yamamoto et al 2014). HLB was discovered in São Paulo, Brazil, in 2004 (Teixeira et al 2005) and in South Florida, USA, in 2005, and has since been found in Belize, Mexico, Texas, and California (Grafton-Cardwell et al 2013). In both Brazil and Florida, the disease has spread rapidly through commercial and residential citrus plantings. 
The management of HLB is presently based on the use of healthy nursery trees, elimination of HLB-symptomatic plants, and especially on the control of $D$. citri (Gottwald 2010). Although it is possible to use systemic insecticides, most insecticide applications are made by foliar applications (more than 25 times a year) (Belasque et al 2010), which may negatively affect the natural enemies, occasioning outbreaks of secondary pests, resurgence of target pests, and selection of resistant populations (Yamamoto \& Bassanezi 2003, Tiwari et al 2011, Guedes \& Cutler 2013).

Tamarixia radiata (Waterston) (Hymenoptera: Eulophidae) is a parasitoid of $D$. citri that has been released as part of biological-control programs for this pest (Pluke et al 2008, Qureshi et al 2009, Hall \& Nguyen 2010, Williams et al 2013). It is a specialized ectoparasitoid (Zuparko et al 2011) that preferentially develops in third to fifth instar nymphs of $D$. citri (Skelley \& Hoy 2004, Hall et al 2013) and also feeds on eggs and first to third instar nymphs (Chu \& Chien 1991). The combined effects of parasitism and feeding allow a single female of T. radiata to eliminate up to 500 psyllid nymphs during its lifetime (Chu \& Chien 1991).

In several countries where the disease occurs, successive releases of $T$. radiata have been conducted in areas of HLB management programs, as well as in areas containing the alternative host of D. citri, Murraya paniculata (L.) Jack (Rutaceae), and in areas near commercial orchards, which are being used for multiplying the ectoparasitoid (Parra et al 2010). However, the use of broad-spectrum insecticides may interfere with the biological control exerted by $T$. radiata. In São Paulo state, parasitism rates that were formerly $80 \%$ declined to less than $26 \%$ due to increased use of pesticides to control D. citri (Gomez-Torres et al 2006, Parra et al 2010, Paiva \& Parra 2012).

To prevent this problem, pest management programs should use selective insecticides that cause relatively little harm to the parasitoid. However, only a few studies have evaluated the toxicity of pesticides to $T$. radiata, such as those of Hall and Nguyen (2010), who among 16 pesticides found only four were compatible with the parasitoid; Tiwari and Stelinski (2013) who reported the low toxicity of cyantraniliprole to $T$. radiata; Beloti et al (2015) who tested 25 insecticides and found only five selective; and Lira et al (2015), who reported only one acaricide considered short lived, among 16 tested. In view of the importance of using the parasitoid $T$. radiata in IPM programs for $D$. citri, this study evaluated the duration of the harmful effects of insecticides that are recommended for the control of insect pests in citrus, on adults of $T$. radiata, in order to contribute to IPM programs that integrate chemical and biological control. The study also compared the toxicity of insecticides to the parasitoid and to $D$. citri.

\section{Material and Methods}

Insects

The populations of $T$. radiata and $D$. citri used in the experiments were obtained from the Insect Biology Laboratory and the Integrated Pest Management Laboratory in the Department of Entomology and Acarology of the 'Luiz de Queiroz' College of Agriculture/University of São Paulo (ESALQ/USP) rearing stocks maintained for several generations on seedlings of orange jasmine, Murraya paniculata (L.) Jack (Rutaceae).

The parasitoids were reared on seedlings of orange jasmine, M. paniculata and using fourth and/or fifth instars $D$. citri nymphs as substrate for female oviposition in acrylic cages $(90 \times 50 \times 50 \mathrm{~cm})$ and in a controlled room (temperature at $25 \pm 2{ }^{\circ} \mathrm{C}$, relative humidity $(\mathrm{RH}) 70 \pm 10 \%$, and a photoperiod of 14 L:10 D h), as described by Parra et al (2016).

\section{Insecticides}

We assessed the effects of 24 insecticides that are recommended for integrated citrus production in Brazil, on the parasitoid $T$. radiata. All products were tested at the Highest Field Concentrations (HRFC) recommended by the Brazilian Ministry of Agriculture, Livestock and Supply (MAPA) (AGROFIT 2016). The insecticides and concentrations (g a.i. liter ${ }^{-1}$ ) used in the bioassays are listed in Table 1. The insecticides were diluted in tap water $(\mathrm{pH} 7.0-7.5)$ for all bioassays.

\section{Duration of harmful effects of insecticides on adults of Tamarixia radiata}

Five Valencia sweet orange seedlings (Citrus sinensis (L.) Osbeck (Rutaceae)), grown in $2-\mathrm{L}$ pots, $80 \mathrm{~cm}$ tall, and with 20 mature leaves, for each treatment, were sprayed with the insecticides or tap water (control treatment) until runoff point using a Guarany backpack sprayer equipped with a TXVS-4 conical nozzle. After the treatments were applied, the seedlings were placed in a greenhouse. Three, 7, 10, 17, 24, and 30 days after the spraying, one fully expanded leaf, which was present at the time of spraying, was randomly removed from each plant and leaf discs of $4.0-\mathrm{cm}$ diameter were obtained with the aid of a metallic punch. The discs were placed in Petri dishes (4.5-cm diameter) containing a gelled mixture of water-agar to $2.5 \%$ to maintain moisture for the leaf disc; each dish was considered an experimental unit. Later, ten $T$. radiata adults up to $48 \mathrm{~h}$ old, of mixed gender from the rearing colony, were anesthetized with $\mathrm{CO}_{2}$ for $5 \mathrm{~s}$ and released in each dish. The dishes were closed with the lid, which had a hole (covered with voile 
Table 1 Insecticides used in bioassays either harmful effects or differential toxicity or both, with their concentrations and chemical group.

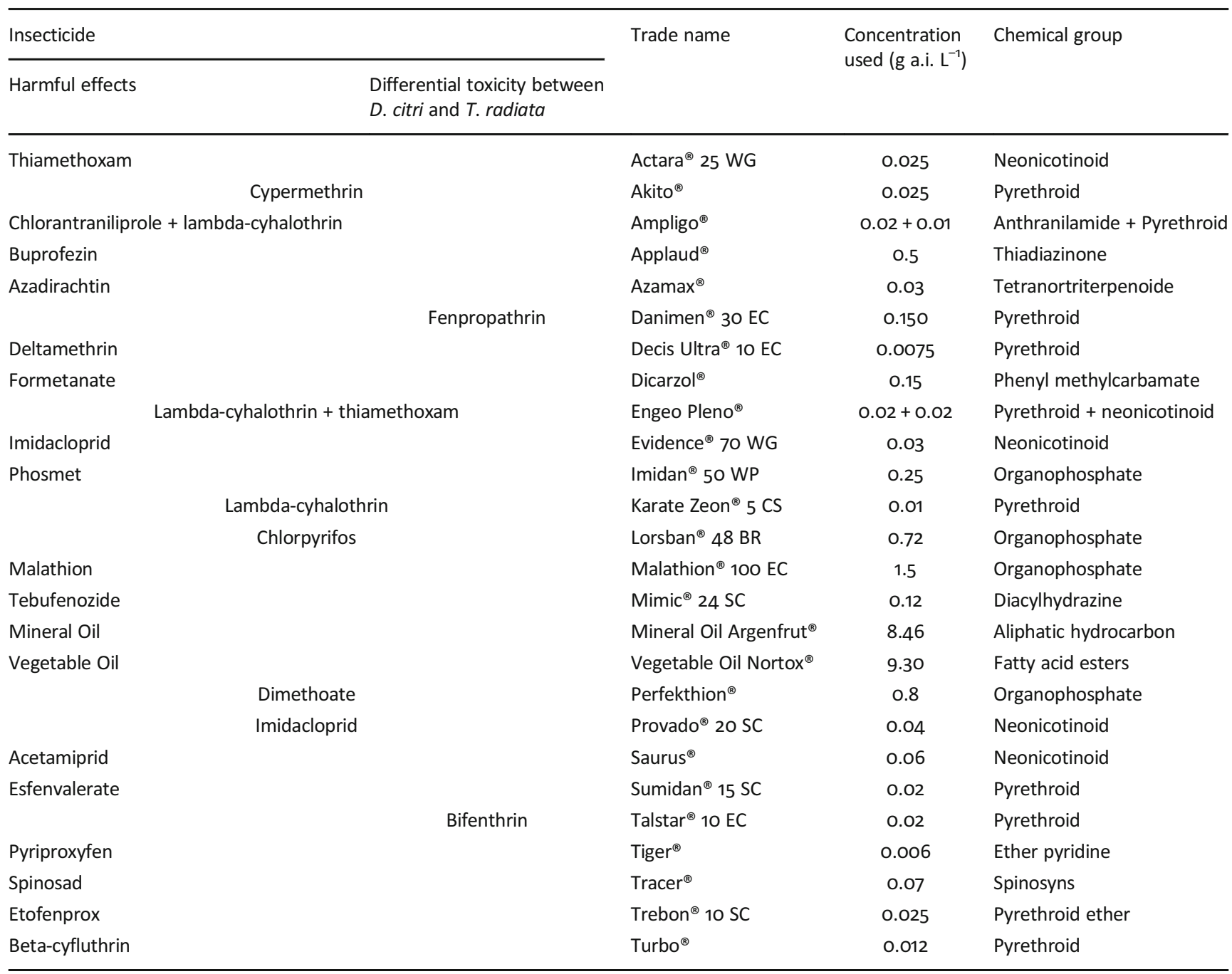

fabric) in the center to allow gas exchange. A drop of pure honey $\left(\sim 1 \mathrm{~mm}^{3}\right)$ was placed once a week on the voile to serve as food for the parasitoids during the evaluation period. Five replicates were used for each treatment $(n=50)$. The bioassay was conducted in a controlled room (temperature at $25 \pm 2^{\circ} \mathrm{C}, \mathrm{RH} 70 \pm 10 \%$, and a photoperiod of $14 \mathrm{~L}: 10 \mathrm{D} \mathrm{h}$ ), using a completely randomized design.

The mortality of the parasitoids was assessed $24 \mathrm{~h}$ after they were exposed to the treated leaves. Insects unable to move when prodded with a fine brush were considered dead. The mortality data for each insecticide and assessment period were corrected by the formula of Abbott (1925). The insecticides that caused less than $30 \%$ of mortality compared to the control treatment (tap water) were classified according to the persistence scale proposed by the International Organization for Biological and Integrated Control of Noxious Animals and Plants/West Palearctic Regional
Section (IOBC/WPRS): class $1-$ short-life ( $<5$ days), class $2-$ slightly persistent (5-15 days), class $3-$ moderately persistent (16-30 days), and class $4-$ persistent (>30 days) (Van de Veire et al 2002).

\section{Duration of harmful effects of different concentrations of insecticide on adults of Tamarixia radiata}

To investigate the effects of different concentrations of insecticides for adults of $T$. radiata, dimethoate, formetanate, and spinosad, the insecticides classified as persistent (class 4 ) in the bioassay for duration of harmful effects were selected. For each insecticide, the HRFC and $0.75 \times$, 0.50x, and $0.25 \times$ HRFC were used (Table 2).

The methods and conditions were the same as in the first bioassay (duration of harmful effects of insecticides on adults of $T$. radiata). 
Differential toxicity of insecticides to Diaphorina citri and Tamarixia radiata

To assess the differential toxicity to the Asian citrus psyllid $D$. citri and the parasitoid $T$. radiata, the insecticides that are most often used in citrus were selected (Table 1). Adults of $D$. citri and $T$. radiata up to $48 \mathrm{~h}$ old, of mixed gender and from the rearing colony, were exposed to insecticide residues sprayed on the Valencia sweet orange seedlings, following the same bioassay method (duration of harmful effects of insecticides on adults of $T$. radiata). Five replicates with ten adults each were used for each treatment $(n=50)$. The bioassay was conducted in a controlled room (temperature $25 \pm$ $2^{\circ} \mathrm{C}, \mathrm{RH} 70 \pm 10 \%$, and a photoperiod of $\left.14 \mathrm{~L}: 10 \mathrm{D} \mathrm{h}\right)$, using a completely randomized design.

Quasi-binomial models (McCullagh \& Nelder 1989) were fitted to the mortality data for each insecticide, with a different linear predictor for each species. Submodels (parallel and coincident linear predictors) were also fitted and compared using $F$ tests. Goodness-of-fit was assessed using half-normal plots with simulated envelopes (Demétrio et al 2014). All analyses were carried out using software R ( $R$ Core Team 2017).

\section{Results}

\section{Duration of harmful effects of insecticides on adults of Tamarixia radiata}

The duration of the harmful effects of the insecticides on adults of $T$. radiata, sprayed on citrus seedlings, showed different IOBC classes, which are present in Table 3. Formetanate, dimethoate, and spinosad were considered persistent for the parasitoid (>30 days, class 4 ) according to the IOBC/WPRS criteria (Table 3). Thiamethoxam, cypermethrin, deltamethrin, phosmet, and etofenprox were considered moderately persistent (16-30 days, class 3) (Table 3). Buprofezin, lambda-cyhalothrin + thiamethoxam, lambdacyhalothrin, malathion, imidacloprid (0.04), and esfenvalerate were considered slightly persistent (5-15 days, class 2 ) (Table 3). Ten of the insecticides tested were harmless to the parasitoid, being considered as short-life ( $<5$ days) (class 1$)$ : chlorantraniliprole + lambda-cyhalothrin, azadirachtin, imidacloprid (0.03), chlorpyrifos, tebufenozide, mineral oil, vegetable oil, acetamiprid, pyriproxyfen, and beta-cyfluthrin (Table 3).

\section{Duration of harmful effects of different concentrations on adults of Tamarixia radiata}

Evaluation of different concentrations of the insecticides considered persistent showed that increasing the
Table 2 Insecticides and their different concentrations used in bioassays of sublethal concentrations on adults of Tamarixia radiata.

\begin{tabular}{lllll}
\hline Treatment & HRFC & $0.75 \times$ HRFC & $0.50 \times$ HRFC & $0.25 \times$ HRFC \\
\hline Spinosad & 0.070 & 0.0525 & 0.035 & 0.0175 \\
Formetanate & 0.150 & 0.1125 & 0.075 & 0.0375 \\
Dimethoate & 0.800 & 0.600 & 0.400 & 0.200 \\
\hline
\end{tabular}

HRFC Highest Recommended Field Concentration by MAPA.

concentration of spinosad increased the duration of the harmful effect (persistence) (Fig 1). With $0.25 \times$ HRFC, the insecticide was considered slightly persistent (class 2); with $0.50 \times$ and $0.75 \times$ HRFC, the insecticide was considered moderately persistent (class 3); and with the HRFC, the insecticide was considered persistent (class 4).

Formetanate caused high mortality of the parasitoids, even if only $0.25 \times$ HRFC was used (Fig 1), and was classified as moderately persistent with this concentration (class 3 ). Formetanate was classified as persistent (class 4) at the other sublethal concentrations tested.

Dimethoate, in contrast to the results from the persistence test, was classified as slightly persistent in all concentrations tested.

\section{Differential toxicity of insecticides to Diaphorina citri} and Tamarixia radiata

The effects of the insecticides on $D$. citri and $T$. radiata differed significantly (Table 4). A significantly different vs. parallel test means that the mortality curves of two species differ. When the same test is not significant, but the parallel vs. coincident test is significant, this means that the mortality curves are parallel, i.e., the mortality decreases similarly over time for both species, but the mortality of one species is always higher than that of the other.

The mortality curves for cypermethrin, dimethoate, and imidacloprid (0.04) were parallel when the insects were compared; but over time, D. citri showed higher mortality than $T$. radiata (Fig 2). However, dimethoate caused $100 \%$ mortality of the parasitoid at 3 days after spraying (DAS).

Lambda-cyhalothrin + thiamethoxam, chlorpyrifos, and bifenthrin also showed parallel mortality curves. However, over time, the mortality of $T$. radiata exceeded that of $D$. citri (Fig 2).

Fenpropathrin caused higher mortality of $D$. citri after 3 DAS; but after 10 DAS, the mortality of the parasitoid was higher than the psyllid. The mortality caused by lambda-cyhalothrin was similar for both species, but presenting a more pronounced mortality on the parasitoid (Fig 2). 
Table 3 Mortality \pm SE (\%) of $T$. radiata adults 1, 3, 7, 10, 17, 24, and 30 days after spraying of the insecticides, and the IOBC/WPRS classes.

\begin{tabular}{|c|c|c|c|c|c|c|c|c|}
\hline \multirow[t]{2}{*}{ Treatment } & \multirow{2}{*}{$\begin{array}{l}\text { Concentration used } \\
\left(\mathrm{g} \text { a.i. } \mathrm{L}^{-1}\right)\end{array}$} & \multicolumn{6}{|c|}{ Mortality \pm SE (\%)-days after spraying (DAS) } & \multirow{2}{*}{$\begin{array}{l}\text { IOBC/WPRS } \\
\text { class }^{\text {a }}\end{array}$} \\
\hline & & 3 & 7 & 10 & 17 & 24 & 30 & \\
\hline Control & - & $0.0 \pm 0.0$ & $2.0 \pm 2.0$ & $4.0 \pm 2.4$ & $2.0 \pm 2.0$ & $2.0 \pm 2.0$ & $2.0 \pm 2.0$ & - \\
\hline Acetamiprid & 0.06 & $36.0 \pm 16.0$ & $8.0 \pm 4.0$ & $8.0 \pm 2.0$ & $10.0 \pm 4.0$ & $10.0 \pm 6.0$ & $16.0 \pm 10.0$ & 1 \\
\hline Azadirachtin & 0.03 & $8.0 \pm 2.0$ & $2.0 \pm 2.0$ & $4.0 \pm 2.4$ & $4.0 \pm 2.4$ & $2.0 \pm 2.0$ & $4.0 \pm 2.4$ & 1 \\
\hline Beta-cyfluthrin & 0.012 & $44.0 \pm 14.0$ & $8.0 \pm 6.0$ & $24.0 \pm 7.0$ & $28.0 \pm 5.0$ & $24.0 \pm 9.0$ & $6.0 \pm 4.0$ & 1 \\
\hline Buprofezin & 0.5 & $82.0 \pm 7.0$ & $40.0 \pm 13.0$ & $18.0 \pm 13.0$ & $28.0 \pm 7.0$ & $18.0 \pm 6.0$ & $32.0 \pm 15.0$ & 2 \\
\hline $\begin{array}{l}\text { Chlorantraniliprole }+ \\
\text { lambda-cyhalothrin }\end{array}$ & $0.02+0.01$ & $38.0 \pm 3.7$ & $16.0 \pm 9.3$ & $8.0 \pm 2.0$ & $2.0 \pm 2.0$ & $2.0 \pm 2.0$ & $4.0 \pm 2.4$ & 1 \\
\hline Chlorpyrifos & 0.72 & $46.0 \pm 2.4$ & $22.0 \pm 2.0$ & $30.0 \pm 3.2$ & $8.0 \pm 4.9$ & $8.0 \pm 2.0$ & $6.0 \pm 2.4$ & 1 \\
\hline Cypermethrin & 0.025 & $96.0 \pm 2.0$ & $68.0 \pm 16.0$ & $36.0 \pm 13.0$ & $30.0 \pm 7.0$ & $14.0 \pm 9.0$ & $14.0 \pm 4.0$ & 3 \\
\hline Deltamethrin & 0.0075 & $78.0 \pm 12.0$ & $32.0 \pm 17.0$ & $34.0 \pm 13.0$ & $30.0 \pm 9.0$ & $26.0 \pm 7.0$ & $24.0 \pm 13.0$ & 3 \\
\hline Dimethoate & 0.8 & $100.0 \pm 0.0$ & $90.0 \pm 6.0$ & $96.0 \pm 4.0$ & $30.0 \pm 12.0$ & $34.0 \pm 12.0$ & $42.0 \pm 10.0$ & 4 \\
\hline Esfenvalerate & 0.02 & $48.0 \pm 2.0$ & $28.0 \pm 2.0$ & $38.0 \pm 2.0$ & $24.0 \pm 5.1$ & $18.0 \pm 5.8$ & $12.0 \pm 4.9$ & 2 \\
\hline Etofenprox & 0.025 & $96.0 \pm 4.0$ & $66.0 \pm 12.0$ & $80.0 \pm 6.0$ & $58.0 \pm 11.0$ & $20.0 \pm 13.0$ & $12.0 \pm 7.0$ & 3 \\
\hline Formetanate & 0.15 & $92.0 \pm 6.0$ & $96.0 \pm 4.0$ & $100.0 \pm 0.0$ & $68.0 \pm 10.0$ & $44.0 \pm 16.0$ & $46.0 \pm 14.0$ & 4 \\
\hline Imidacloprid & 0.03 & $30.0 \pm 4.5$ & $20.0 \pm 4.5$ & $22.0 \pm 6.6$ & $26.0 \pm 2.4$ & $22.0 \pm 3.7$ & $4.0 \pm 2.4$ & 1 \\
\hline Imidacloprid & 0.04 & $40.0 \pm 3.2$ & $36.0 \pm 6.8$ & $24.0 \pm 6.8$ & $8.0 \pm 5.8$ & $14.0 \pm 2.4$ & $8.0 \pm 2.0$ & 2 \\
\hline Lambda-cyhalothrin & 0.01 & $70.0 \pm 10.0$ & $40.0 \pm 14.0$ & $32.0 \pm 18.0$ & $24.0 \pm 12.0$ & $20.0 \pm 5.0$ & $2.4 \pm 1.3$ & 2 \\
\hline $\begin{array}{l}\text { Lambda-cyhalothrin + } \\
\text { thiamethoxam }\end{array}$ & $0.02+0.02$ & $50.0 \pm 0.0$ & $48.0 \pm 2.0$ & $30.0 \pm 3.2$ & $20.0 \pm 3.2$ & $16.0 \pm 4.0$ & $16.0 \pm 4.0$ & 2 \\
\hline Malathion & 1.5 & $44.0 \pm 0.40$ & $34.0 \pm 0.40$ & $16.0 \pm 4.0$ & $14.0 \pm 2.4$ & $6.0 \pm 4.0$ & $4.0 \pm 2.4$ & 2 \\
\hline Mineral oil & 8.46 & $12.0 \pm 4.0$ & $6.0 \pm 2.0$ & $12.0 \pm 2.0$ & $18.0 \pm 4.0$ & $8.0 \pm 6.0$ & $8.0 \pm 4.0$ & 1 \\
\hline Phosmet & 0.25 & $40.0 \pm 4.5$ & $44.0 \pm 4.0$ & $44.0 \pm 2.4$ & $34.0 \pm 6.0$ & $22.0 \pm 3.7$ & $6.0 \pm 4.0$ & 3 \\
\hline Pyriproxyfen & 0.006 & $46.0 \pm 2.4$ & $18.0 \pm 3.7$ & $8.0 \pm 3.7$ & $4.0 \pm 2.4$ & $6.0 \pm 2.4$ & $6.0 \pm 2.4$ & 1 \\
\hline Spinosad & 0.07 & $100.0 \pm 0.0$ & $80.0 \pm 15.0$ & $98.0 \pm 2.0$ & $84.0 \pm 7.0$ & $48.0 \pm 15.0$ & $56.0 \pm 10.0$ & 4 \\
\hline Tebufenozide & 0.12 & $28.0 \pm 12.0$ & $10.0 \pm 5.0$ & $16.0 \pm 6.0$ & $30.0 \pm 14.0$ & $18.0 \pm 7.0$ & $12.0 \pm 8.0$ & 1 \\
\hline Thiamethoxam & 0.025 & $48.0 \pm 2.0$ & $40.0 \pm 3.2$ & $42.0 \pm 5.8$ & $38.0 \pm 2.0$ & $18.0 \pm 2.0$ & $4.0 \pm 2.4$ & 3 \\
\hline Vegetable oil & 9.30 & $34.0 \pm 16.0$ & $6.0 \pm 2.0$ & $10.0 \pm 4.0$ & $16.0 \pm 10.0$ & $10.0 \pm 5.0$ & $18.0 \pm 9.0$ & 1 \\
\hline
\end{tabular}

${ }^{\mathrm{a}} \mathrm{OOBC} /$ WPRS class based on the duration of the harmful effect of insecticides: class $1=$ short-life $(<5$ days $)$, class $2=$ slightly persistent $(5-15$ days $)$, class $3=$ moderately persistent (16-30 days), and class $4=$ persistent $(>30$ days $)$.

\section{Discussion}

In our study, the interaction complexes between the insecticides and the plant were not analyzed. On the other hand, the effects of the residues of 24 insecticides recommended for citrus were evaluated on the ectoparasitoid $T$. radiata. The results showed that chlorantraniliprole + lambda-cyhalothrin, azadirachtin, imidacloprid (0.03), chlorpyrifos, tebufenozide, mineral oil, vegetable oil, acetamiprid, pyriproxyfen, and beta-cyfluthrin were considered as short-life.

For azadirachtin and tebufenozide, our results agree with those reported by Biondi et al (2013), Momanyi et al (2012), and Zhao et al (2012), who classified these insecticides as short-life (class 1) for different species of parasitoids. Tebufenozide, a member of the insect growth-regulator group (IGRs), affects larvae more than adults (Sieber and Rembold 1983), and together with azadirachtin, a botanical product, is generally considered safe for the environment and for natural enemies (Chen et al 2013) and can be recommended for IPM programs.

For $T$. radiata, buprofezin was slightly persistent. This result agrees with the findings reported by Rugno et al (2016) for the lacewing Ceraeochrysa cincta (Schneider) (Neuroptera: Chrysopidae). This insecticide is a chitin biosynthesis inhibitor type 1 (IGR) and affects immature stages more than adults.

The three neonicotinoids studied differed in their effects. Acetamiprid showed the lowest persistence of harmful effects, followed by imidacloprid (class 1 or 2 depending on the concentration) and thiamethoxam. This difference may be either related to the generation of neonicotinoids or due to molecules degradation. Thiamethoxam is a secondgeneration neonicotinoid (Maienfisch et al 2001) that acts differently from the first-generation imidacloprid and acetamiprid. Thiamethoxam is able to bind to mixed nicotinic/ muscarinic receptors (Lapied et al 1990), and this mechanism 

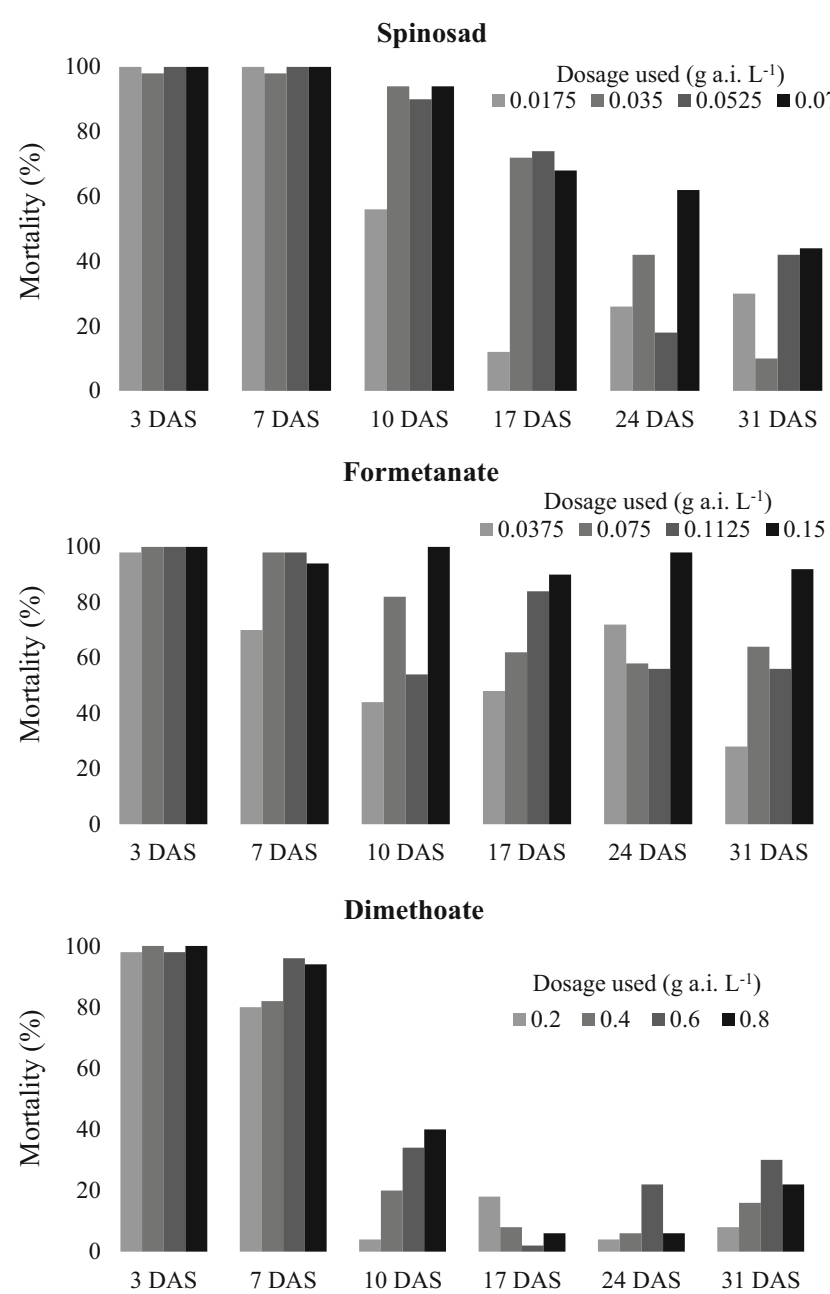

Fig 1 Mortality (\%) of $T$. radiata adults 1, 3, 7, 10, 17, 24, and 30 days after spraying of the different concentrations of three insecticides.

or site of action may increase the effect of thiamethoxam on T. radiata, unlike imidacloprid and acetamiprid.

The divergent results for the action on $T$. radiata probably are not related to the type of pyrethroid. With the exception of etofenprox, which is a non-ester pyrethroid, the others are type II (Soderlund \& Bloomquist 1989). The difference between the results obtained here may be related to the pyrethroid generation. Deltamethrin and cypermethrin, the oldest pyrethroids (Khambay 2002), were more harmful to the parasitoid, while the newer pyrethroids were more selective and less persistent.

The results for lambda-cyhalothrin and malathion differ from those obtained by Momanyi et al (2012), who classified lambda-cyhalothrin as persistent (class 4) and malathion as moderately persistent (class 3 ) for two species of Trichogramma. These differences in classification can be explained by the difference in the substrate, by the concentrations and inert components of the insecticides, and also by the insect species used in the bioassays. Species of the genus Trichogramma can be more sensitive than adults of $T$. radiata, perhaps because of their smaller body size. While adult males of Trichogramma measure 0.5 to $0.65 \mathrm{~mm}$ in length and adult females from 0.46 to $0.62 \mathrm{~mm}$ (Carver 1978), the body length of $T$. radiata adults ranges from 0.92 to $1.3 \mathrm{~mm}$ (Waterston 1922, Onagbola et al 2009, Chen \& Stansly 2014).

In our study, formetanate was classified as persistent (class 4). These results differ from those obtained by Brunner et al (2001), who found that formetanate caused high mortality in adults of Colpoclypeus florus (Walker) (Hymenoptera: Eulophidae) up to 14 DAS. This divergence may be related to differences in the commercial product used, i.e., the concentrations and inert components of the insecticides.

Spinosad is sometimes classified as reduced-risk environmentally and toxicologically, considered an organic material, and usually less harmful to predators, but wasp parasitoids are significantly more susceptible to its effects (Williams et al 2003). In our study, spinosad was classified as persistent (class 4) for $T$. radiata adults. Similarly, Biondi et al (2013) classified spinosad as harmful to $B$. nigricans. According to Biondi et al (2012), spinosad is acutely toxic to many hymenopteran parasitoids, with high levels of mortality, marked typical poisoning symptoms, and reduced mobility after exposure.

Therefore, insecticides such as formetanate, dimethoate, and spinosad should be used judiciously in IPM programs,
Table 4 Statistical tests for nested models fitted to the data for differential toxicity per species $(P<0.05)$

\begin{tabular}{lll}
\hline Insecticide & $\begin{array}{l}\text { Different vs. parallel } \\
\text { linear predictors }\end{array}$ & $\begin{array}{l}\text { Parallel vs. coincident } \\
\text { linear predictors }\end{array}$ \\
\hline $\begin{array}{l}\text { Cypermethrin } \\
\text { Fenpropathrin }\end{array}$ & $F_{1,56}=0.02, P=0.88$ & $F_{1,57}=29.41, P<0.01$ \\
Lambda-cyhalothrin + thiamethoxam & $F_{1,56}=7.62, P<0.01$ & $F_{1,57}=27.05, P<0.01$ \\
Lambda-cyhalothrin & $F_{1,56}=2.59, P=0.11$ & $F_{1,57}=5.50, P=0.02$ \\
Chlorpyrifos & $F_{1,56}=0.42, P=0.52$ & $F_{1,57}=0.01, P=0.91$ \\
Dimethoate & $F_{1,56}=0.24, P=0.65$ & $F_{1,57}=55.11, P<0.01$ \\
Imidacloprid & $F_{1,56}=0.48, P=0.49$ & $F_{1,57}=19.93, P<0.01$ \\
Bifenthrin & $F_{1,56}=2.57, P=0.11$ & $F_{1,57}=6.22, P=0.02$ \\
\hline & $F_{1,56}=0.06, P=0.81$ & $F_{1,57}=10.78, P<0.01$ \\
\hline
\end{tabular}



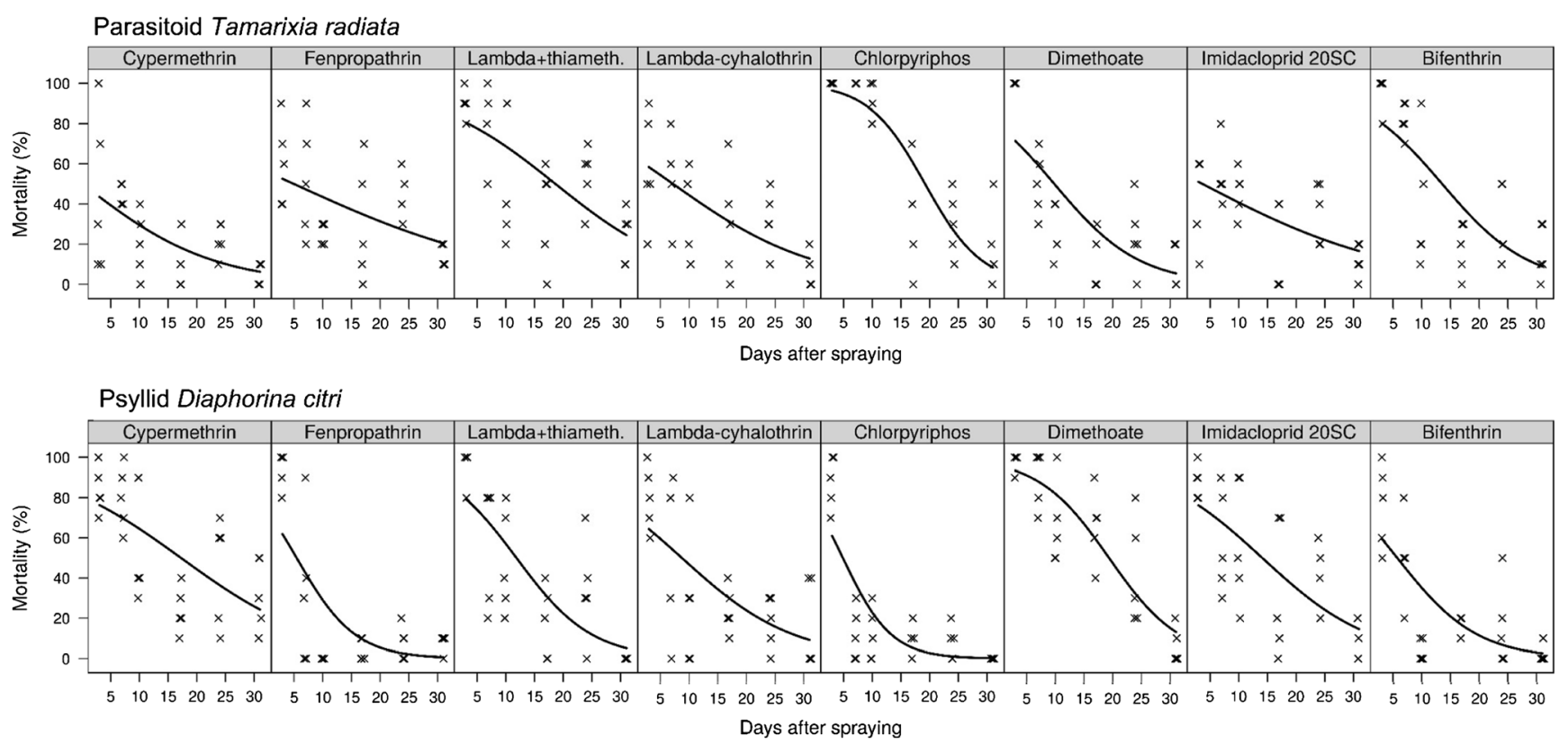

Fig 2 Mortality (\%) of the parasitoid Tamarixia radiata and the psyllid Diaphorina citri caused by the most frequently used insecticides over time.

during periods when $T$. radiata does not occur naturally in the field or that do not coincide with parasitoid releases.

Similar studies of persistence should be performed under field conditions to determine the most appropriate time to release $T$. radiata after a particular insecticide is sprayed. Plants in the field are exposed to rain, moisture, sunlight, and other abiotic factors that can affect the persistence of insecticides.

Evaluation of the differential toxicity of insecticides to the psyllid $D$. citri and the parasitoid $T$. radiata showed that lambda-cyhalothrin and lambda-cyhalothrin + thiamethoxam affected the two species similarly. Field studies have found that these insecticides reduced the psyllid population up to 33 DAS (Yamamoto et al 2009).

In our study, dimethoate caused high mortality of the psyllid. Similarly, Yamamoto et al (2009), evaluating the efficiency of foliar application of dimethoate, observed reduction of the adult population within $1 \mathrm{~h}$ after spraying, and the population remained low until 33 DAS.

Cypermethrin caused higher mortality of $D$. citri than of $T$. radiata during the entire bioassay and can be recommended for use in IPM programs. Imidacloprid (0.04), despite causing high mortality of the psyllid at 3 DAS, did not differ in the other evaluation periods for both insects. When applied as a soil drench, this insecticide is effective against $D$. citri up to 30 DAS (Miranda et al 2016).

Chlorpyrifos and bifenthrin were more harmful to the parasitoid than to the psyllid. Therefore, these insecticides should be avoided during periods when the parasitoids are released or when they occur naturally in the field.

Insecticides of the same chemical group affected the mortality of the pest and the natural enemy differently. While the organophosphate dimethoate caused higher mortality of the psyllid, chlorpyrifos caused higher mortality of the parasitoid. Among the pyrethroids, cypermethrin caused high mortality of the psyllid, fenpropathrin caused similar mortalities of both insects, and bifenthrin caused high mortality of the parasitoid. These variations in mortality can be aggravated or attenuated because of the active ingredients, inert substances, formulations, toxicological classification, molecular weight, application method, weather conditions, and different concentrations of the insecticides, which may raise or lower the relative mortality of different insect species (Cox \& Surgan 2006).

The few studies reporting the differential toxicity of insecticides to $D$. citri and $T$. radiata indicate that, when the mortality of the psyllid was higher than that of the parasitoid, the difference in the toxicity to the two species was related to physiological selectivity (Ripper et al 1951, Degrande et al 2002). That is, when these insects came into direct contact with the insecticide residues, the insecticide impacted the pest more than the natural enemy (Degrande et al 2002, Foerster 2002). Physiological selectivity involves the processes of absorption, penetration, transport, and activation of insecticides, which, when they act at different intensities, result in different toxicity to two species (Foerster 2002).

The information provided by this study, and knowledge of the lethal and sublethal effects of different pesticides on the parasitoid T. radiata (Beloti et al 2015, Lira et al 2015), will enable citrus growers to select the most appropriate insecticides that both control the psyllid $D$. citri and are less toxic to its parasitoid $T$. radiata. This will allow both chemical and biological-control methods to be used in conjunction, in accordance with one of the IPM principles. 
Acknowledgments The authors thank Dr. Jaci Mendes Vieira and Dr. Alexandre Diniz from the Insect Biology Laboratory of ESALQ/USP for providing the parasitoids at the beginning of the experiments and Janet W. Reid for revising the English text.

Funding information This study was funded by the CAPES Foundation (Brazilian Ministry of Education), the São Paulo State Foundation for Research Aid (FAPESP), and the National Council for Scientific and Technological Development (CNPq grant 305828/2014-2).

\section{References}

Abbott WS (1925) A method of computing the effectiveness of an insecticide. J Econ Entomol 18:265-267

AGROFIT (2016) Sistema de Agrotóxicos Fitossanitários - Ministério da Agricultura, Pecuária e Abastecimento, Brasil http://agrofit. agricultura.gov.br/agrofit_cons/principal_agrofit_cons/ Accessed 21 Mar 2016

Alemán JH, Baños H, Ravelo J (2007) Diaphorina citri y la enfermedad huanglongbing: una combinación destructiva para la producción citrícola. Ver Prot Veg 22:154-165

Belasque J Jr, Bassanezi RB, Yamamoto PT, Ayres AJ, Tachibana A, Violante AR, Tank A Jr, Giorgis F, Tersi FEA, Menezes GM, Dragone J, Jank RH Jr, Bové JM (2010) Lessons from Huanglongbing management in São Paulo state, Brazil. J Plant Pathol 92:285-302

Beloti VH, Alves GR, Araújo DFD, Picoli MM, Moral RA, Demétrio CGB, Yamamoto PT (2015) Lethal and sublethal effects of insecticides used on citrus, on the ectoparasitoid Tamarixia radiata. PLoS One 10(7): e0132128. https://doi.org/10.1371/journal.pone.0132128

Biondi A, Mommaerts V, Smagghe G, Viñuela E, Zappalà L, Desneux N (2012) The non-target impact of spinosyns on beneficial arthropods. Pest Manag Sci 68:1523-1536

Biondi A, Zappalà L, Stark JD, Desneux N (2013) Do biopesticides affect the demographic traits of a parasitoid wasp and its biocontrol services through sublethal effects? PLoS One 8(9):e76548. https://doi.org/10. 1371/journal.pone.0076548

Brunner JF, Dunley JE, Doerr MD, Beers EH (2001) Effect of pesticides on Colpoclypeus florus (Hymenoptera: Eulophidae) and Trichogramma platneri (Hymenoptera: Trichogrammatidae), parasitoids of leafrollers in Washington. J Econ Entomol 94:1075-1084

Carver M (1978) A new subgenus and species of Trichogramma Westwood (Hymenoptera: Chalcidoidea) from Australia. Aust J Entomol 17:109-112

Chen X, Stansly PA (2014) Biology of Tamarixia radiata (Hymenoptera: Eulophidae), parasitoid of the citrus greening disease vector Diaphorina citri (Hemiptera: Psylloidea): a mini review. Fla Entomol 97:1404-1413

Chen X, Song M, Qi S, Wang C (2013) Safety evaluation of eleven insecticides to Trichogramma nubilale (Hymenoptera: Trichogrammatidae). J Econ Entomol 106:136-141

Chu YI, Chien CC (1991) Utilization of natural enemies to control of psyllid vectors transmitting citrus greening. In: Kiritani K, Su HJ, Chu YI (eds) Integrated control of plant virus disease. Food and Fertilizer Technology Center for the Asian and Pacific Region, Taipei, pp 135145

Coletta-Filho HD, Targon MLPN, Takita MA, De Negri JD, Pompeu J Jr, Machado MA (2004) First report of the causal agent of Huanglongbing ("Candidatus Liberibacter asiaticus") in Brazil. Plant Dis 88:1382-1382

Cox C, Surgan M (2006) Unidentified inert ingredients in pesticides: implications for human and environmental health. Environ Health Perspect 114:1803-1806. https://doi.org/10.1289/ehp.9374
Degrande PE, Reis PR, Carvalho GA, Belarmino LC (2002) Metodologia para avaliar o impacto de pesticidas sobre inimigos naturais. In: Parra JRP, Botelho PSM, Corrêa-Ferreira BS, Bento JMS (eds) Controle biológico no Brasil: parasitóides e predadores. Manole, SP, Brazil, pp 71-93

Demétrio CGB, Hinde J, Moral RA (2014) Models for overdispersed data in entomology. In: Ferreira CP, Godoy WAC (eds) Ecological modelling applied to entomology, Cham, Switzerland

Foerster LA (2002) Seletividade de inseticidas a predadores e parasitoides. In: Parra JRP, Botelho PSM, Corrêa-Ferreira BS, Bento JMS (eds) Controle biológico no Brasil: parasitóides e predadores. Manole, SP, Brazil, pp 95-114

Gomez-Torres ML, Nava DE, Gravena S, Costa VA, Parra JRP (2006) Registro de Tamarixia radiata (Waterston) (Hymenoptera: Eulophidae) em Diaphorina citri Kuwayama (Hemiptera: Psyllidae) em São Paulo. Rev Agric (Piracicaba, Brazil) 81:112-117

Gottwald TR (2010) Current epidemiological understanding of citrus Huanglongbing. Annu Rev Phytopathol 48:119-139

Grafton-Cardwell E, Stelinski LL, Stansly PA (2013) Biology and management of Asian citrus psyllid, vector of the Huanglongbing pathogens. Annu Rev Entomol 58:413-432

Guedes RNC, Cutler GC (2013) Insecticide-induced hormesis and arthropod pest management. Pest Manag Sci 70:690-697

Hall DG, Nguyen R (2010) Toxicity of pesticides to Tamarixia radiata, a parasitoid of the Asian citrus psyllid. BioControl 55:601-611

Hall DG, Richardson ML, Ammar ED, Halbert SE (2013) Asian citrus psyllid, Diaphorina citri, vector of citrus Huanglongbing disease. Entomol Exp Appl 146:207-223

Khambay B (2002) Pyrethroid insecticides. Pesticide Outlook 2002:4954. https://doi.org/10.1039/b202996k Available online http://www. researchinformation.co.uk/pest/2002/B202996K.PDF

Lapied B, LeCorronc H, Hue B (1990) Sensitive nicotinic and mixed nicotinic-muscarinic receptors in insect neurosecretory cells. Brain Res 533:132-136

Lira ACS, Zanardi OZ, Beloti VH, Bordini GP, Yamamoto PT, Parra JRP, Carvalho GA (2015) Lethal and sublethal impacts of acaricides on Tamarixia radiata (Hemiptera: Eulophidae), an important Ectoparasitoid of Diaphorina citri (Hemiptera: Liviidae). J Econ Entomol 108:2278-2288

Maienfisch P, Angst M, Brandl F, Fischer W, Hofer D, Kayser H, Kobe W, Rindlisbacher A, Senn R, Steinemann A, Withmer H (2001) Chemistry and biology of thiamethoxam: a second generation neonicotinoid. Pest Manag Sci 57:906-913

McCullagh P, Nelder JA (1989) Generalized linear models. Boca Raton, Florida

Miranda MP, Yamamoto PT, Garcia RB, Lopes JPA, Lopes JRS (2016) Thiamethoxam and imidacloprid drench applications on sweet orange nursery trees disrupt feeding and settling behaviour of Diaphorina citri (Hemiptera: Liviidae). Pest Manag Sci 72:1785-1793

Momanyi G, Maranga R, Sithanantham S, Agong S, Matoka CM, Hassan SA (2012) Evaluation of persistence and relative toxicity of some pest control products to adults of two native trichogrammatid species in Kenya. BioControl 57:591-601

Onagbola EO, Boina DR, Hermann SL, Stelinski LL (2009) Antennal sensilla of Tamarixia radiata (Hymenoptera: Eulophidae), a parasitoid of Diaphorina citri (Hemiptera: Psyllidae). Ann Entomol Soc Am 102:523531

Paiva PEB, Parra JRP (2012) Natural parasitism of Diaphorina citri Kuwayama (Hemiptera, Psyllidae) nymphs by Tamarixia radiata Waterston (Hymenoptera, Eulophidae) in São Paulo orange groves. Rev Bras Entomol 56:499-503

Parra JRP, Lopes JRS, Torres MLG, Nava DE, Paiva PEB (2010) Bioecologia do vetor Diaphorina citri e transmissão de bactérias associadas ao huanglongbing. Citrus Res Technol 31:37-51

Parra JRP, Alves GR, Diniz AJF, Vieira JM (2016) Tamarixia radiata (Hymenoptera: Eulophidae) $\times$ Diaphorina citri (Hemiptera: Liviidae): 
mass rearing and potential use of the parasitoid in Brazil. J Integ Pest Manag 7:1-11

Pluke RWH, Qureshi JA, Stansly PA (2008) Citrus flushing patterns, Diaphorina citri (Hemiptera: Psyllidae) populations and parasitism by Tamarixia radiata (Hymenoptera: Eulophidae) in Puerto Rico. Fla Entomol 91:36-42

Qureshi JA, Rogers ME, Hall DG, Stansly PA (2009) Incidence of invasive Diaphorina citri (Hemiptera: Psyllidae) and its introduced parasitoid Tamarixia radiata (Hymenoptera: Eulophidae) in Florida citrus. J Econ Entomol 102:247-256

R Core Team (2017) R: A language and environment for statistical computing. R Foundation for Statistical Computing. Vienna, Austria. URL: https://www.R-project.org/

Ripper WE, Greenslade RM, Hartley GS (1951) Selective insecticides and biological control. J Econ Entomol 44:448-458

Rugno GR, Zanardi OZ, Cuervo JB, Morais MR, Yamamoto PT (2016) Impact of insect growth regulators on the predator Ceraeochrysa cincta (Schneider) (Neuroptera: Chrysopidae). Ecotoxicology. https://doi.org/10.1007/s10646-016-1651-9

Sieber KP, Rembold H (1983) The effects of Azadirachtin on the endocrine control of molting in Locusta migratoria. J Insect Physiol 29:523527

Skelley LH, Hoy MA (2004) A synchronous rearing method for the Asian citrus psyllid and its parasitoids in quarantine. BioControl 29:14-23

Soderlund DM, Bloomquist JR (1989) Neurotoxic actions of pyrethroid insecticides. Annu Rev Entomol 34:77-96. https://doi.org/10.1146/ annurev.en.34.010189.000453

Teixeira DC, Danet JL, Eveillard S, Martins EC, Cintra de Jesus W, Yamamoto PT, Lopes SA, Bassanezi RB, Ayres AJ, Saillard C, Bové JM (2005) Citrus Huanglongbing in São Paulo, Brazil: PCR detection of the 'Candidatus' Liberibacter species associated with the disease. Mol Cell Probes 19:173-179
Tiwari S, Stelinski LL (2013) Effects of cyantraniliprole, a novel anthranlic diamide insecticide, against Asian citrus psyllid under laboratory and field conditions. Pest Manag Sci 69:1066-1072

Tiwari S, Sayed RS, Sayed ME, Stelinski LL (2011) Insecticide resistance in field populations of Asian citrus psyllid in Florida. Pest Manag Sci 67: 1258-1268

Van de Veire M, Sterk G, Van der Staaij M, Ramakers PMJ, Tirry L (2002) Sequential testing scheme for the assessment of the side-effects of plant protection products on the predatory bug Orius laevigatus. BioControl 47:101-113

Waterston J (1922) On the chalcidoid parasites of psyllids (Hemíptera: Homoptera). Bull Entomol Res 13:41-58

Williams T, Valle J, Viñuela E (2003) Is the naturally derived insecticide Spinosad ${ }^{\circledR}$ compatible with insect natural enemies? Biocontrol Sci Tech 13:459-475. https://doi.org/10.1080/0958315031000140956

Williams T, Arredondo-Bernal HC, Del Bosque LAR (2013) Biological pest control in Mexico. Annu Rev Entomol 58:119-140

Yamamoto PT, Bassanezi RB (2003) Seletividade de produtos fitossanitários aos inimigos naturais de pragas dos citros. Laranja 24 : 353-382

Yamamoto PT, Felippe MR, Sanches AL, Coelho JHC, Garbim LF, Ximenes NL (2009) Eficácia de inseticidas para o manejo de Diaphorina citri Kuwayama (Hemiptera: Psyllidae) em citros. BioAssay 4:1-9

Yamamoto PT, Alves GR, Beloti VH (2014) Manejo e controle do huanglongbing (HLB) dos cítricos. Investig Agrar 16:69-82

Zhao X, Wu C, Wang Y, Cang T, Chen L, Yu R, Wang Q (2012) Assessment of toxicity risk of insecticides used in rice ecosystem on Trichogramma japonicum, an egg parasitoid of rice lepidopterans. J Econ Entomol 105:92-101

Zuparko RL, Queiroz DL, La-Salle J (2011) Two new species of Tamarixia (Hymenoptera: Eulophidae) from Chile and Australia, established as biological control agents of invasive psyllids (Hemiptera: Calophyidae, Triozidae) in California. Zootaxa 2921:13-27 